\title{
波浪による海底地盤内間隙水圧変動解の適用性と地盤の液状化条件 \\ APPLICABILITY OF SOLUTIONS FOR TRANSIENT WAVE-INDUCED POREWATER PRESSURES IN SEABED AND LIQUEFACTION CONDITIONS OF SEABED
}

\author{
酒井哲 郎*・畑中克也** ・間瀬肇*** \\ By Tetsuo SAKAI, Katsuya HATANAKA and Hajime MASE
}

\begin{abstract}
There exist three solutions for the transient wave-induced porewater pressures in seabed, the seepage flow solution ${ }^{16)}$, the exact solution ${ }^{6)}$ and the boundary region approximation solution ${ }^{10)}$ of Biot's consolidation equations ${ }^{9)}$. Applicability of three solutions is shown graphically in terms of non-dimensional parameter for surf zone conditions. One of the important parameters is the ratio of the shear modulus of solid skelton to the effective bulk modulus of porewater. Another is a non-dimensional quantity proportional to the permeability coefficient and the shear modulus. As the former becomes large and the latter becomes small, the seepage flow solution can not be used but the boundary region approximation solution becomes applicable. Under such situation, the possibility of the vertical effective stress of solid skelton being zero under the wave trough increases. The maximum depth of zero stress is about one half of the wave height.

Keywords : transient wave-induced porewater pressure, vertical effective stress, seabed liquefaction, surf zone
\end{abstract}

\section{1. まえがき}

最近，海岸に設置されたコンクリートブロックがしだ いに沈下し埋没してしまうという現象が報告され，その 原因として，波の作用によって生じる地盤の有効応力の 減少とそれに伴う液状化 ${ }^{1)}{ }^{2)}$ が挙げられている. ここで の有効応力の減少および液状化とは次のことをいう．波 の谷の位相では, 地盤内間隙水圧は海底面に働く波圧ほ ビ減少せずしかも位相が遅れるため, 間隙水圧が余分に 荷重を受け持つことになり, その分地盤骨格の有効応力 が減少する. 海底面付近では土被り圧が小さいため, こ の減少量が土被り圧よりも大きくなると地盤が一時的に 液状化する．なお，ここでは繰り返し応力によるいわゆ る間隙水圧の残留成分の増加の現象は対象としていな い.

波浪によって生じる海底地盤内間隙水圧変動を説明す る簡単な理論モデルとしては鉛直一次元のものがあ $り^{1), 3)}$, 数値モデルとしては有限要素法によるものがあ $3^{4), 5)}$. 名合 ${ }^{1)}$ 善ら $^{3)}$ はこれらのモデルを用いて, その

* 正会員 工博 京都大学助教授 工学部土木工学科 ( ₹606 京都市左京区吉田本町)

** JR 西日本

*** 正会員 工博 京都大学助手 工学部土木工学科
上部に水をたたえた砂層が設置された円筒容器の上部に 周期的な加減圧を加える実験装置により測定された間陌 水圧変動を説明しているが，実際の海岸の場合を考える と鉛直一次元のモデルは普遍性がない。 また，有限要素 法による数值モデルも現象の普遍的な解釈には適さな い.

より一般的な解析解としては, Yamamoto ら ${ }^{6)}$, Mad$\operatorname{sen}^{7)}$ および Okusa ${ }^{8)}$ の Biot ${ }^{9\}}$ の圧密の式あるいは Biot 型の式を解いた厳密解がある。しかしながらこれらの解 は現象を理解するうえでは適さないため, Mei and $F_{\text {oda }}{ }^{10\}}$ は海底地盤全体を一相の弾性体として扱う一方, 排水が容易な海底面付近の薄い層状領域においては間隙 水亡地盤骨格の相対速度を考慮して補正するという近似 （境界領域近似よよぶ）を行って, 近似解を求めた。こ の解は, 上述の 3 つの箃密解に比べて形が簡単で扱いが 容易である.

著者ら ${ }^{11), 12)}$ は, この境界領域近似の手法を用いて, Mei らが無視した加速度項および海底面に働くせれ断 力の効果を検討した。一方，砕波帯のような浅い海域を 想定し, Mei らの近似解を用いて鉛直有効応力変化を 計算し，液状化に対して支配的な波浪および地盤に関す る無次元パラメーターとその影響を検討した ${ }^{13)}$.ただし, そこでは近似解そのものの適用範囲を検討していなかっ 
た。

本研究では Yamamoto ら ${ }^{6}$ の厳密解と Mei $ら^{10)}$ の近 似解を比較することにする．この場合も砕波帯のような 浅い海域を想定して, 無次元パラメーターを用いて一般 的に議論をする.より簡単な解として, 地盤を剛と仮定 した浸透流の扱い ${ }^{14)}$ で間隙水圧を求め, 地盤骨格の有効 応力は一相の弾性体としての全応力の解 $\left.{ }^{15}\right)$ か上述の間 隙水圧を差し引いて与える方法がある ${ }^{16)}$ (uncoupled analysis とよぶ). 本研究ではこの uncoupled analysis の解と簃密解との比較も行って, 3 者の適用範囲を明ら かにする。

また, 有効応力変化の計算 ${ }^{13)}$ では, 有効応力の変動を 海底面での波圧と間隙水圧変動の差 ${ }^{3)}$ として近似的に与 えたが，その妥当性を検討するため Mei $ら^{10)}$ の鉛直有 効応力変動解とこの近似表現を比較する.

最後に，液状化に支配的なパラメーターの検討13)では 波浪に関する無次元パラメーターの值が 1 ケースのみで あったので，ここでは他の值のケースを加えて，より一 般的に波浪によって海底地盤骨格の鉛直有効応力が 0 に なる条件およびその発生深さを明らかにする，ただしこ こでは地盤のパラメーターの効果に着目しており, また 砕波帯の波を対象としていることから, 波浪パラメ一 ターの効果に関しては結果のみを示して詳細な議論はし ない.

\section{2. 波浪による海底地盤内間隙水圧変動と有効 応力変動の解}

\section{（1）Yamamoto ら ${ }^{6}$ および Madsen ${ }^{7}$ の厳密解}

Yamamoto ${ }^{6)}$ P Madsen $^{7)}$ は, 波浪による変動圧力 によって生じる海底地盤内の間隙水圧や有効応力に関す る研究において, 地盤骨格と間隙水の双方の運動を考慮 した二相モデルを用いている，このモデルは, 海底地盤 が多孔性の弾性体で Hooke の法則に従い, 間隙水が圧

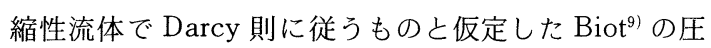
密の式とよばれるものである.その解析解の形は複雑で, 現象を理解するのには適さない.

\section{(2) Mei and Foda ${ }^{10)}$ の近似解}

Mei and Foda ${ }^{10)}$ は, 地盤骨格と間隙水のそれぞれの 連続式と運動方程式をいくつかの仮定を用いて変形し, 地盤骨格と間隙水の速度が等しいとして一相で扱う外部 領域と, 両者の相対速度が無視できない海底面近くの境 界領域（Fig.1）とでおのおの解を求め, 両者の和を最 終の解とする近似解法を示した。 またその解はY Yamamoto $ら^{6)}$ の厳密解とほぼ一致することを示した. 上述 の仮定には, 微小变位の仮定, 地盤骨格に対する線形弾 性体の仮定, 間隙水におけるせん断応力の無視, 間隙水 の圧力と密度の線形関係の仮定, 地盤骨格と間隙水との

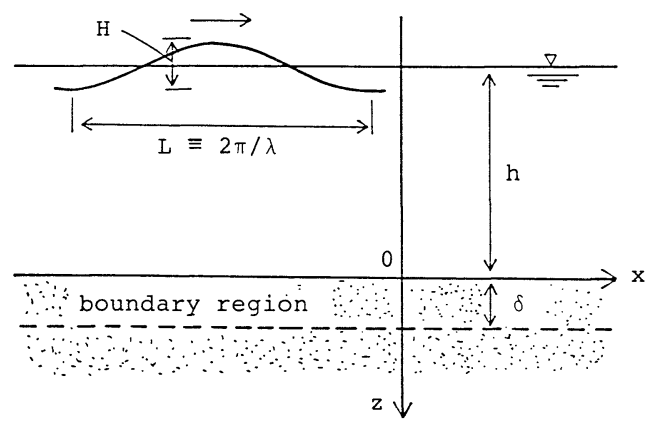

Fig. 1 Boundary region of Mei and Foda ${ }^{10)}$.

干渉力における Darcy 則の仮定, 地盤骨格および間隙 水の加速度と重力が無視できるという仮定, 波長に比べ て境界領域厚さが小さいという仮定が含まれる.

外部領域では, 正弦波状に変動する振動荷重が表面を 一定速度で移動する場合の半無限弾性体の疑似静的な変 形の問題となり，すでに解は求められている。一方境界 領域では, Terzaghi の一次元圧密の問題となる．境界 領域解の未知定数は, 両者の間隙水圧変動の解の和が海 底面での波圧変動に一致することから決定される.

海底面での波圧変動 $p_{b}$ が微小振偪波理論による

$$
p_{b}=p_{0} \cdot \cos (\lambda x-\omega t)
$$

$$
=1 / 2 \cdot \rho_{w} g H / \cosh (\lambda h) \cdot \cos (\lambda x-\omega t) \cdot \cdots
$$

で与えられる場合の間隙水圧変動 $p$ は, 次式のように 求められる.

$$
\begin{aligned}
p= & p_{0} \cdot 1 /(1+m) \cdot \exp (-2 \pi z / L) \cdot \cos (\lambda x-\omega t) \\
& +p_{0} \cdot m /(1+m) \cdot \exp \{-z /(\sqrt{2} \delta)\} \\
& \times[\cos \{z /(\sqrt{2} \delta)\} \cdot \cos (\lambda x-\omega t) \\
& -\sin \{z /(\sqrt{2} \delta)\} \cdot \sin (\lambda x-\omega t)] \cdots \cdots \cdots \cdots \cdots(
\end{aligned}
$$

ここで, $p_{0}$ : 海底面での波圧変動振幅, $\rho_{w}$ : 海水の密度, $g$ : 重力加速度, $H:$ 波高, $\lambda:$ 波数, $h:$ 水深, $x:$ 波 の進行方向座標, $\omega$ : 波の角周波数, $t$ : 時間, $z$ : 地 盤深度 (海底面を原点とし鉛直下向き正), $L:$ 波長て ある.パラメーター $m$ および境界領域厚さ $\delta(\ll L)$ は, 次式で与えられる.

$$
\begin{aligned}
& m=n /(1-2 \nu) \cdot G / \beta \\
& \delta=(K G / \omega)^{1 / 2} \\
& \times\{n \cdot G / \beta+(1-2 \nu) / 2(1-\nu)\}^{-1 / 2}
\end{aligned}
$$

ここで, $n$ : 間隙率, $\nu$ :ポアソン比, $G$ : 地盤骨格の せん断弾性係数, $\beta$ : 間隙水の有効体積弾性係数, $K \equiv$ $k /\left(\rho_{w} g\right)(k:$ 透水係数 $)$ である.

式 (2) の右辺第 1 項が外部領域解, 第 2 項が境界領 域解である. 外部領域解は波圧と同位相で地盤の深さ方 向に減衰する，境界領域解は深さ方向に外部領域解より かなり早く減衰するとともに， $\delta$ のスケールで位相も変 化する．両者の相対的な大きさはパラメーター $m$ に依 存し, $m$ が大きいほど境界領域解が支配的になる. 


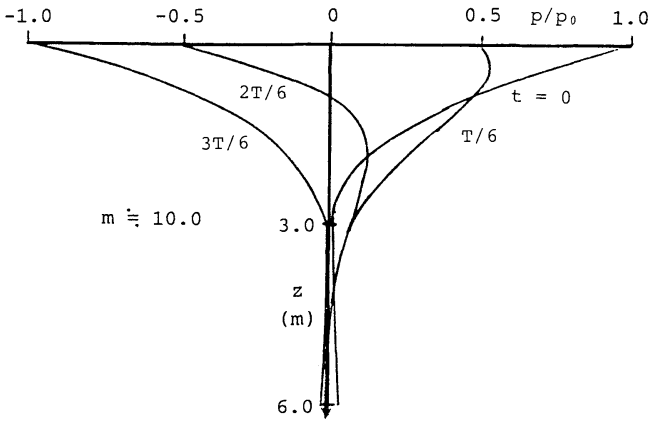

Fig. 2 Vertical distribution of porewater pressure variation (Mei and Foda's approximate solution ${ }^{10)}, m \fallingdotseq 10$ ).

Fig. 2 は，水深 $4.0 \mathrm{~m}$ ，波の周期 $7.0 \mathrm{~s}$, 波長約 $40 \mathrm{~m}$, 海底地盤の間隙率 $1 / 3$, ポアソン比 $1 / 3$, せん断弾性係 数 $1.0 \times 10^{8} \mathrm{~N} / \mathrm{m}^{2}$, 透水係数 $2.8 \times 10^{-4} \mathrm{~m} / \mathrm{s}$, 間隙水の 有効体積弾性係数 $1.0 \times 10^{7} \mathrm{~N} / \mathrm{m}^{2}, m \fallingdotseq 10$ の場合の $p /$ $p_{0}$ の鉛直分布を特定の位相について示したものである. $t=0$ が波の峰の位相である。この場合は境界領域解が 支配的で, $z$ 方向にも位相が変化し $z=3 \mathrm{~m}$ 付近で $p /$ $p_{0}$ がほぼ 0 になる。

\section{( 3 ) uncoupled analysis ${ }^{16)}$}

Finn ${ }^{16)}$ は, 土粒子骨格の変形を無視し間隙水を非 圧縮と仮定して, 浸透流解析法 ${ }^{14)} に よ り$ 地盤内部の間隙 水圧を求める一方, 地盤の有効応力は一相の弾性体とし て計算される全応力と上記の間隙水圧との差として求め ることを提案している。 そこでは土粒子骨格と間隙水の 相互作用を無視しており，Finn らはこのような解析の 方法を uncoupled analysis と名付けている.

彼らは, 地盤層厚が無限で, 透水係数が方向によらず, 間隙水が非生縮性である（地盤骨格のせん断弾性係数が 間隙水の有効体積弾性係数より小さい) 場合, Yamamoto $ら^{6)}$ の間隙水圧の厳密解と uncoupled analysisに よって得られた解が一致することを示している。また同 様の条件下では，正弦波状の荷重下における半無限弾性 地盤内に働く鉛直全応力 ${ }^{15)}$ と uncoupled analysis に よって得られた間陌水圧との差が, Yamamoto らの厳 密解による鉛直有効応力に等しいと述べている.

さらに彼らは, 地盤骨格のせん断弾性係数および透水 係数の值をそれぞれ二通りとし, “硬くて粗い”, “硬く て細かい”，“柔らかくて粗い”，“柔らかくて細かい”の 4 つのタイプの海底地盤について, Biot の式 ${ }^{9}$ に基づい て開発した数值計算プログラムによる解と uncoupled analysis の解とを比較している．その結果，地盤の層厚 が無限で透水係数が方向によらない場合, “硬くて細か い砂”の場合を除いて両者はほぼ一致すると述べている.

\section{3. 間隙水圧変動解の適用範囲}

\section{（1）無次元化}

以上のように，Finn ら ${ }^{16)}$ は，Biotの式を用いなくて も簡単な uncoupled analysis が多くの場合に適用でき る可能性を示唆しているが，特定のパラメーターだけに 対しての検討で終わっている.ここでは，より一般的に uncoupled analysis が適用できる範囲を明らかにするた めに，厳密解と比較するにあたって無次元量を用いて検 討する.ただし，Yamamoto らや Madsenによる厳密 解は形が複雑すぎるため, 支配的な無次元量を抽出する にあたってはMei らの間隙水圧変動の境界領域近似 解 $^{{ }^{0)}}$ を利用した。 その手順は以下のようである.

地盤内の間隙水圧変動の近似解 (式 $(2))$ の両辺を 海底面での波圧の振幅 $p_{0}$ で割ると次式を得る。ただし， ここでは砕波帯のようなきわめて浅い状態を想定してい るので, $\cosh (\lambda h) \fallingdotseq 1.0,2 \pi / \lambda \equiv$ 波長 $\fallingdotseq T \sqrt{g h}$ と近似 している.

$$
\begin{aligned}
p / p_{0}= & 1 /(1+m) \cdot \exp (-2 \pi z / L) \cdot \cos \theta \\
& +m /(1+m) \cdot \exp \{-z /(\sqrt{2} \delta)\} \\
& \times[\cos \{z /(\sqrt{2} \delta)\} \cdot \cos \theta \\
& -\sin \{z /(\sqrt{2} \delta)\} \cdot \sin \theta] \cdots \ldots \ldots \ldots \ldots \ldots \ldots \ldots
\end{aligned}
$$

ここで,

$$
\begin{aligned}
& \theta=\lambda x-\omega t \\
& z / L=(T \sqrt{g / h})^{-1} \cdot H / h \cdot z / H \\
& z /(\sqrt{2} \delta)=\left(k G / \rho_{w} g^{2} T h\right)^{-1 / 2} \cdot z / L \\
& \times\{n \cdot G / \beta+(1-2 \nu) / 2(1-\nu)\}^{1 / 2}
\end{aligned}
$$

上式と式 $(3)$ からわかるように，無次元間隙水圧変 動 $p / p_{0}$ は, 地盤に関する無次元量 $n, \nu$ および $G / \beta$ 亡, 波に関する無次元量 $T \sqrt{g / h}$ および $H / h$, さらに両者 に関係する無次元量 $k G / \rho_{w} g^{2} T h$ をパラメーターとし て, 波の位相 $\theta$ と無次元深度 $z / H$ の関数として与えら れる.

$$
\begin{array}{r}
p / p_{0}=p / p_{0}(\theta, z / H ; T \sqrt{g / h}, H / h, n, \nu, G / \beta, \\
\left.k G / \rho_{w} g^{2} T h\right) \cdots \cdots \cdots \cdots \cdots \cdots \cdots \cdots \cdots(\text { ( })
\end{array}
$$

このうち, 間隙率 $n$ とポアソン比 $\nu$ はそれほど大きく 変化しない。ここでは $n=\nu=1 / 3$ とする，波に関する パラメーター $T \sqrt{g / h}$ および $H / h$ は砕波帯のような 浅い領域を想定して, たとえば $h=4.0 \mathrm{~m}, T=7.0 \mathrm{~s}$, $H=3.0 \mathrm{~m}$ とすると, $T \sqrt{g / h} \fallingdotseq 11.0$ および $H / h=$ 0.75 となる.そこでここでは $T \sqrt{g / h}=15.0$ と $H / h$ $=0.5$ の場合を加えて 4 つの組合せを考える.

残る 2 つ無次元パラメーター $G / \beta$ と $k G / \rho_{w} g^{2} T h$ については，次のように考える，砂地盤を対象とし，そ の場合の典型的な值として $k=2.8 \times 10^{-4} \mathrm{~m} / \mathrm{s}, \quad G=1.0$ $\times 10^{8} \mathrm{~N} / \mathrm{m}^{2}$ とする ${ }^{17)}$. 一方, 間陌水の有効体積弾性係数 $\beta$ は, 間隙水の飽和度との間に経験的な関係があり ${ }^{17)}$, 
わずかな気体の混入によって大きく減少するとされてい る. 完全飽和の場合は $\beta \fallingdotseq 2 \times 10^{9} \mathrm{~N} / \mathrm{m}^{2}$ であるのに対し て， $1 \%$ の気体の混入によって $10^{6} \mathrm{~N} / \mathrm{m}^{2}$ に減少する. 先

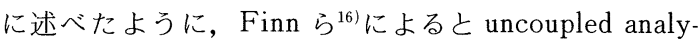
sis は硬くて細かい砂に対して適用できない。ここでい う硬い砂とは間隙水との相対的な硬さのことであるの で，柔らかい水と考えることもできる．そのような条件 を考えて， $\beta=1.0 \times 10^{6} \mathrm{~N} / \mathrm{m}^{2}$ とする．以上の值を用い ると $G / \beta=1.0 \times 10^{2}, k G / \rho_{w} g^{2} T h=1.0 \times 10^{-2}$ となる. これらの值を参考にし，しかも $\beta=1.0 \times 10^{6} \mathrm{~N} / \mathrm{m}^{2}$ は極

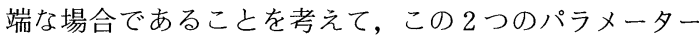
を $10^{-1}<G / \beta<10^{2}, 10^{-3}<k G / \rho_{w} g^{2} T h<1$ の範囲で変 化させた（Table 1)．ただし以下の図では $10^{-1}<G / \beta$ $<10^{1}$ の範囲を示している.

（2）厳密解6) と uncoupled analysis ${ }^{16)}$ の解との比較

Fig. 3 は, $n=\nu=1 / 3, T \sqrt{g / h}=11.0, H / h=0.75$, $G / \beta=1 \times 10^{1}$ および $k G / \rho_{w} g^{2} T h=1 \times 10^{-1}$ の場合の Yamamoto らの厳密解 ${ }^{6)}$ と Finn ${ }^{16)}$ の uncoupled analysis による変動間隙水圧の鉛直分布を示している. 水圧は海底面での波圧振幅 $p_{0}$ で無次元化してある。両 者はかなり異なっているが，その相違を表わす代表量と して $t=3 T / 6$ （波の谷の位相）での両者の差の最大值 を用いる.この場合は， $z=6.5 \mathrm{~m}$ 付近で現われる.

Fig. 4 は, $n=\nu=1 / 3, T \sqrt{g / h}=11.0, H / h=0.75$ の場合の波圧振幅 $p_{0}$ で無次元化した両者の差の最大值 の等值線を, 横軸に $G / \beta$, 縦軸に $k G / \rho_{w} g^{2} T h$ をとつ

Table.1 Non-dimensional parameters.

$\begin{aligned} T \sqrt{g / h} & =11.0,15.0 \\ H / h & =0.5,0.75 \\ n & =1 / 3 \\ \nu & =1 / 3 \\ G / \beta & =1.0 \times 10^{-1} \sim 1.0 \times 10^{2}\end{aligned}$

$k G / \rho_{w} g^{2} T h=1.0 \times 10^{-3} \sim 1.0$

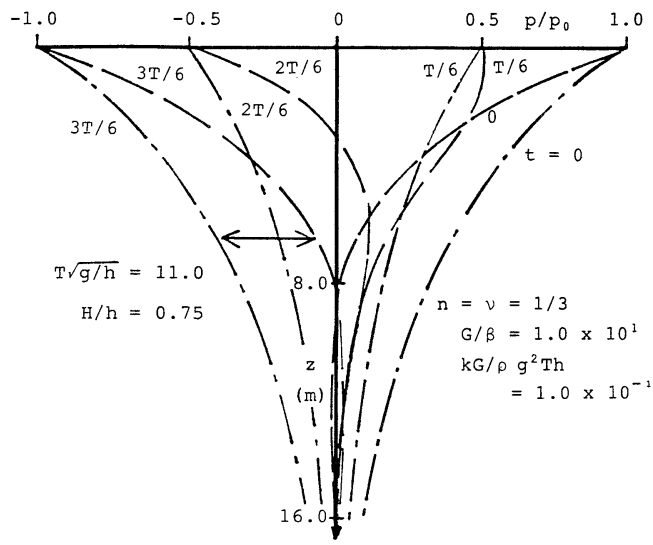

Fig. 3 Comparison between exact solution ${ }^{6)}(--)$ and uncoupled analysis ${ }^{16)}(-\cdots)$.
て示したものである.

前に述べたように，ここでは Fig. 4 の場合を含めて $T \sqrt{g / h}=15.0$ と $H / h=0.5$ の場合を加えた 4 つの組 合せについて計算している. その結果 $H / h=0.5$ の場 合は Fig.4のそれとほとんど同じであったが， $T \sqrt{g / h}$ を 15.0 にすると等値線全体が左斜め上に平行移動する 傾向がみられた。たとえば, Fig. 4 では横軸, 縦軸の值 がそれぞれ約 $1.3,1.0 \times 10^{-1}$ の場合に 0.05 となってい るが， $T \sqrt{g / h}$ が 15.0 の場合には横軸, 縦軸の值が約 $0.80,1.0 \times 10^{-1}$ の場合に 0.05 となる.

全体の傾向として，G/B が増加するほどまた $k G /$ $\rho_{w} g^{2} T h$ が減少するほぼ，差が大きくなる， $G / \beta$ が増加 するということは，間隙水に対する土粒子骨格の相対的 な硬さが増すということであり，また $k G / \rho_{w} g^{2} T h$ が減 少するということは, 透水係数が減少すること, つまり 土粒子が細かくなることと考えられる.このようにここ での解析は, Finn らが示した uncoupled analysis が“硬 くて細かい砂”に対して適用できないという事実を一般 的に示したものである.

\section{(3) 撖密解6) と境界領域近似解 ${ }^{10)} の$ 比較}

以上のように, uncoupled analysis の解の誤差の大き さ，すなわちその適用範囲は明らかになったが，uncoupled analysis が使えない場合でも, Yamamoto $ら^{6)}$ の箃密解は手計算では計算できない。そこで次に，厳密 解之 Mei らの境界領域近似解 ${ }^{10)}$ との比較を, ( 2 ) で行っ たのと同一の手法, 同一の条件で検討する.

Fig. 5 は, $n=\nu=1 / 3, T \sqrt{g / h}=11.0, H / h=0.75$ の場合の, 波圧振幅 $p_{0}$ で無次元化した波の谷の位相で の間隙水圧変動の両者の差の最大値の等値線を, Fig. 4 と同様に横軸に $G / \beta$, 縦軸に $k G / \rho_{w} g^{2} T h$ をとって示

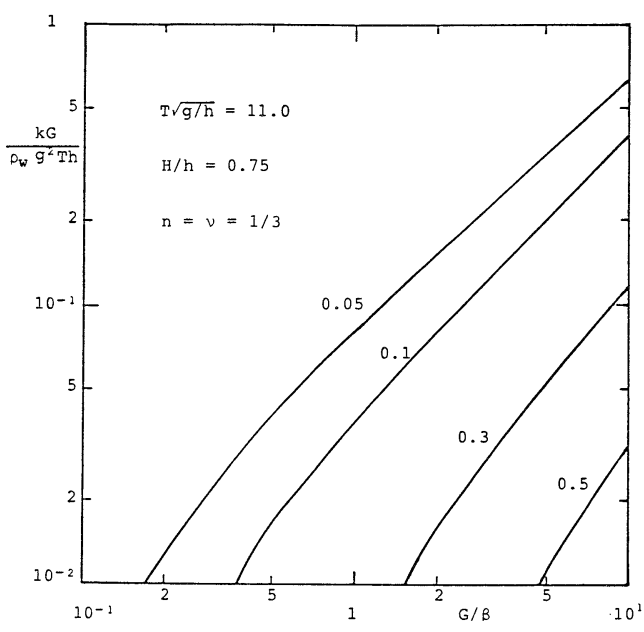

Fig. 4 Difference of non-dimensional porewater pressure between exact solution ${ }^{6)}$ and uncoupled analysis ${ }^{16)}$. 


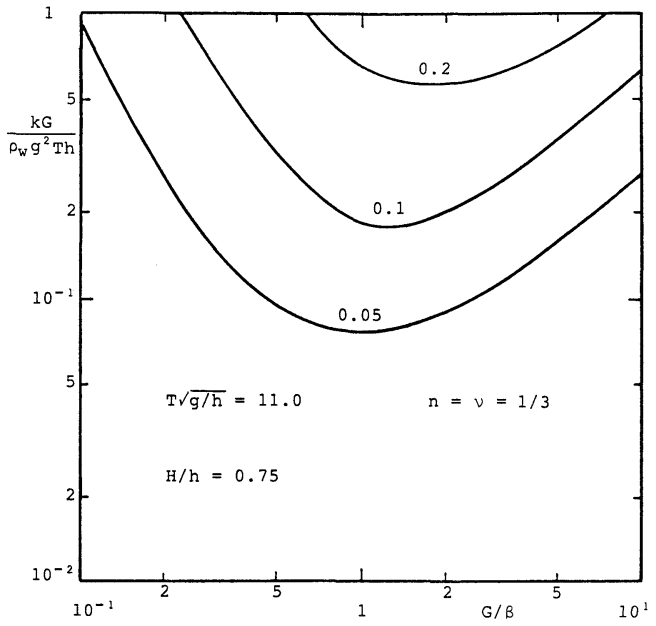

Fig. 5 Difference of non-dimensional porewater pressure between exact ${ }^{6)}$ and approximate solutions ${ }^{10)}$.

したものである.

$T \sqrt{g / h}$ と $H / h$ の值の他の組合せの場合に関しても 同様の図を作ったが，その結果，厳密解と uncoupled analysis 解との比較の場合と同様， $H / h$ を 0.5 として も傾向は変わらず， $T \sqrt{g / h}$ が 15.0 の場合に等值線が 全体に上に移動する傾向がみられた．Fig. 5 の場合 0.05 の等值線の極小值は $k G / \rho_{w} g^{2} T h \fallingdotseq 8.0 \times 10^{-2}$ 付近であ るが， $T \sqrt{g / h}=15.0$ の場合は $1.1 \times 10^{-1}$ 程度になる.

全体の傾向として, $k G / \rho_{w} g^{2} T h$ が $1.0 \times 10^{-1}$ より大 きい範囲で厳密解と近似解の差が生じる， $G / \beta$ の值が およそ 1.0 の付近で, 両者の差が生じる $k G / \rho_{w} g^{2} T h$ の 值の範囲が最も広く $8.0 \times 10^{-2}$ 程度まで広がるが， $G / \beta$ がそれより減少しても増加しても，両者の差が生じる $k G / \rho_{w} g^{2} T h$ の值は大きい範囲に限られる。 これは次の ように考えることができる， $k G / \rho_{w} g^{2} T h$ は，式 ( 8 ) からわかるように，その $1 / 2$ 乗が境界領域厚さ $\delta に$ 比 例している，そのため，その值が大きくなると境界領域 厚さが増加し，境界領域厚さが薄いとした境界領域近似 解の仮定に反することになり, 境界領域近似解の適用範 囲を逸脱することになる。一方 $G / \beta$ は，式 $(3)$ で示 したように $m$ を通して境界領域解の相対的な大きさに 関係する. $G / \beta$ の值が小さいときには $m$ も小さく外部 領域解が卓越して，上で述べた境界領域厚さが大きいこ とによる影響は現われにくくなる．また式（4）功わ かるように $G / \beta$ が逆に大きくなると境界領域厚さが減 少して近似の仮定を満たすことになり, 近似解が適用で きるようになる。

\section{（4）適用範囲}

以上のように, uncoupled analysis 解と厳密解の差, 厳密解と近似解の差が量的に明らかになったので，ここ

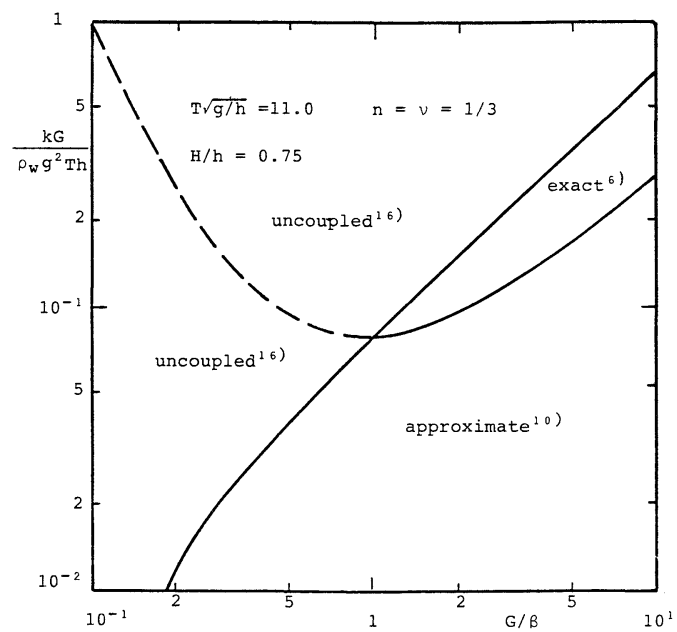

Fig. 6 Application region of exact ${ }^{6)}$, approximate solutions ${ }^{10)}$ and uncoupled analysis ${ }^{16)}$.

では uncoupled analysis 解および近似解の適用し得る 範囲ならびに厳密解を用いなければならない範囲を検討 する. 基準としては海底面での波圧振幅 $p_{0}$ で無次元化 した差が 0.05 となる場合を考える. Fig. 6 は $T \sqrt{g / h}$ $=11.0$ および $H / h=0.75$ の場合の uncoupled analysis 解と厳密解および厳密解之近似解の差が 0.05 となる曲 線を一緒に示したものである。この図から uncoupled analysis 解亡厳密解の差の曲線より左上側では uncoupled analysis 解が適用でき, それより右下側では近似 解を用いる必要があるが，その境界の一部では厳密解を 用いなければならない領域があることがわかる。

なお他の $T \sqrt{g / h}, H / h$ の值の場合に関しては, 前 に述べたように $H / h$ の值が変化してもほとんだ変化せ ず， $T \sqrt{g / h}$ の值が 15.0 の場合には全体的にやや曲線 が上側に移動する．たとえば厳密解を用いなければなら ない領域の $k G / \rho_{w} g^{2} T h$ の最小值は, $T \sqrt{g / h}=11.0$ の 場合の $8.0 \times 10^{-2}$ 加ら $1.2 \times 10^{-1}$ 程度に増加する。

\section{(5) 現地観測結果 ${ }^{18)}$ との比較}

以上のように 3 つの解の適用範囲が明らかになったの で, 次に実測結果との比較を行う. 波圧変動による地盤 内間隙水圧変動に関しては, すでに円筒形の容器の下部 に地盤を設置し, 上部の水に圧力を加えて地盤表面に水 圧変動が㗢くようにした実験装置によった実験結果があ $ろ^{1), 3)}$.これらの実験では地盤層厚が有限でありまた側 方非排水であるため，ここで議論してきた無限層厚の条 件には合わない。

一方無限層厚に対応する実測結果としては，これまで に実際の海岸で測定した例が二，三あるが，特に鉛直分 布を議論し得るものは唯一善ら ${ }^{18}$ のものがあるにすぎな い. 善らは, 運輸省港湾技術研究所波崎海洋研究施設の 
栈橋先端の水深約 $4.0 \mathrm{~m}$ の地点で，昭和 63 年 4 月 12 日〜 5 月 13 日の間に, 海底面から $2 \mathrm{~m}$ の深さまでの地 盤内で，同一鉛直線上の 3 点で波浪による間隙水圧変動 を同時に測定した．有義波高が $100 \mathrm{~cm}$ 以上の波の有義 波周期は 6 10 s であった. 観測記録から選んだ 1 波に ついて，間隙水圧変動の振幅の鉛直分布を示したのが Fig.7である.この図は原論文の図一17 を書き直したも のであり, 横軸の間隙水圧変動振幅 $p_{\max }$ は海底面の波 圧変動振幅で無次元化してある.

この場合の波形そのものも原論文の図に示されてお り, 正確ではないがその周期も読み取れて, 約 $14.3 \mathrm{~s}$ である.この場合の $T \sqrt{g / h}$ の值は約 22 となる. 原論 文では境界領域近似解を求めるために必要なパラメ一 ターの值は示されていないが, 透水係数に関しては室内 実験から $2.2 \times 10^{-2} \mathrm{~cm} / \mathrm{s}$ という值がわかっている。こ こでは現地の地盤が一般的な砂地盤であることを考えて 以下のように值を設定した. $n=\nu=1 / 3, k=2.8 \times 10^{-4}$ $\mathrm{m} / \mathrm{s}$ ，および $G=1.0 \times 10^{8} \mathrm{~N} / \mathrm{m}^{2}$ である. 残りの間隙水 の有効体積弾性係数 $\beta$ は, Fig. 7 の実測值に合うように 値を変えた。

Fig.7の 4 つの実線の曲線は, $\beta$ の值を図中に示した ように $3 \times 10^{7} \mathrm{~N} / \mathrm{m}^{2}$ から $6 \times 10^{6} \mathrm{~N} / \mathrm{m}^{2}$ まで変えた場合の Mei らの近似解である式（2）の $\theta=0$ (波の峰の位相） における結果を示している. 横軸の定義加, 海底面 $z$ $=0$ での值は 1.0 に一致する. 3 つの測定值を同時に説 明する曲線はないが，下二点に一致する $\beta$ としては $3 \times$ $10^{7} \mathrm{~N} / \mathrm{m}^{2}$ ，一番上の実測值に一致する $\beta$ としては $6 \times$ $10^{6} \mathrm{~N} / \mathrm{m}^{2}$ 以下となる。これらの場合の $G / \beta$ の值はそれ ぞれ 3.3 および $1.2 \times 10^{1}$ 以上となり, $k G / \rho_{w} g^{2} T h$ の值 は $5.1 \times 10^{-3}$ となる。 $T \sqrt{g / h}$ の值は, Fig. 6 の 11.0 の約 2 倍であるが， $T \sqrt{g / h}$ の值が増加すると Fig. 6 の曲線は上側に移動することから， $G / \beta=3.3$ および

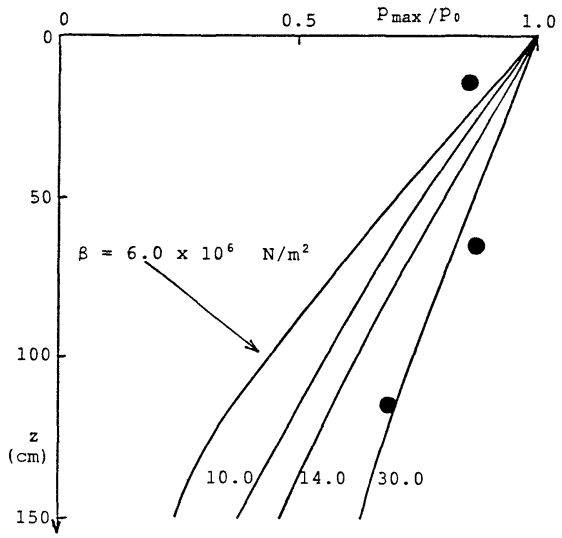

Fig. 7 Comparison between approximate solution ${ }^{10)}$ and field measurement ${ }^{18)}$
$1.2 \times 10^{1}$ 以上いずれの場合も uncoupled analysis が適 用できず，近似解が適用できる範囲に入っている.

なお，Fig. 2 の例でわかるように $\beta$ が小さくて $m$ が 大きい場合には，鉛直方向にも位相が変化し， $\theta=0$ の 位相での鉛直分布が必ずしも間隙水圧変動の振幅の鉛直 分布と一致しない.Fig.7の 4 つのケースに関してその 鉛直分布の位相変化を調べたところ, $\beta$ の值が最も小さ い $6 \times 10^{6} \mathrm{~N} / \mathrm{m}^{2}$ の場合には, $z>1.0 \mathrm{~m}$ の部分で振幅が $\theta=0$ の位相での值より若干大きくなるが，そのほかの 場合は $\theta=0$ での值を振幅とみなし得ることがわかって いる.

\section{4. 波浪による海底地盤鉛直有効応力の減少と 液状化}

\section{（1）有効応力変動の近似表現}

最近, 海岸構造物の前面や離岸堤に用いられるコンク リート異型ブロックがしだいに海底地盤内に沈下してい く現象があるといわれている。この原因として，前述の 波浪による海底地盤内の間隙水圧変動か関係していると いう意見がある ${ }^{1), 2)}$. 鉛直有効応力は，鉛直全応力から 間隙水圧を差し引いたものである．鉛直全応力は，海底 面付近では水中土被り圧と水圧の和として近似できる. 水圧は, 静水状態での静水圧と海底面に働く波圧変動の 和として与えられる，一方間隙水圧は，静水状態での静 水圧と波浪による間隙水圧変動の和として与えられる. したがって鉛直有効応力は，近似的に次式で与えられ $ろ^{3)}$.

鉛直有効応力 $\fallingdotseq$ 水中土被り圧

$$
\begin{aligned}
& \text { 十海底面での波圧変動 }\left(p_{b}\right) \\
& \text { 一間隙水圧変動 }(p)
\end{aligned}
$$

Fig. 8 は，善ら ${ }^{3)}$ の図一3をそのまま示したものであ る，左の図は，(1)の場合は波の谷での，(2)の場合は波の 峰での間隙水圧を示している. 2. ( 2 ) で述べたように, 間隙水圧変動は深さ方向に減衰し，海底面での波圧変動
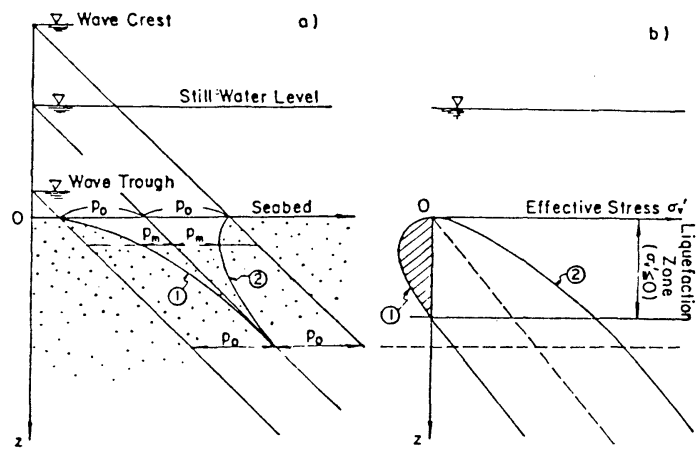

Fig. 8 Effective stress variation and liquefaction in seabed under wave action ${ }^{3)}$. 
よりその振幅が小さくなる，右の図の破線は水中土被り 圧を示すが，波の谷の位相では式（10）の右辺第 2 項と 3 項の差が負になり, 海底面付近ではその絶対值が水中 土被り圧より大きくなって，鉛直有効応力が負になる可 能性があることを示している.

式（10）を用いて地盤骨格の有効応力を計算した例之

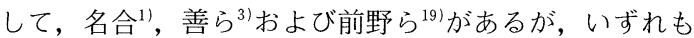
特殊なケースのみに終わっている。酒井ら ${ }^{131}$ は，より一 般的に計算するため前述の Mei らの近似解 ${ }^{10)}$ を用い, 3.（1）と同じ無次元化を行って，波浪により海底地盤 の地盤骨格の鉛直有効応力が減少し 0 になる条件を明ら かにした。

ただし，式（10）はあくまで近似表現であることから， ここでは改めて Hooke の法則を考慮している近似解の 鉛直有効応力と式（10）との比較を行って, 式（10）の 適用性を確認する．また波浪の無次元量の值に関しては 1 ケースのみであったので，別のケースについても同様 の検討を行うことにする。

\section{（2）近似表現の妥当性}

Mei $~^{10)}$ は，境界領域近似により地盤骨格の鉛直有効 応力の変動分 $\sigma_{33}$ を以下のように求めた (ただし実数部 のみを考え，引張りを正としている).

$$
\begin{aligned}
\sigma_{33} / p_{0}= & \{-m /(1+m)-2 \pi z / L\} \exp (-2 \pi z / L) \\
& \times \cos (\lambda x-\omega t) \\
& +m /(1+m) \cdot \exp (-z / \sqrt{2} / \delta) \\
& \times \cos (\lambda x-\omega t+z / \sqrt{2} / \delta) \cdots \cdots \cdots \cdots \cdots . . .
\end{aligned}
$$

また式（2）および（10）を用いた近似的な鉛直有効応 力変動分は以下のように表わされる（引張りを正として いるので, 式 (10) と符号が逆になる).

$$
\begin{aligned}
\sigma_{33} / p_{0}= & \left(p-p_{b}\right) / p_{0} \\
= & 1 /(1+m) \cdot \exp (-2 \pi z / L) \cos (\lambda x-\omega t) \\
& +m /(1+m) \cdot \exp (-z / \sqrt{2} / \delta) \\
& \times \cos (\lambda x-\omega t+z / \sqrt{2} / \delta) \\
& -\cos (\lambda x-\omega t) \cdots \cdots \cdots \cdots \cdots \cdots \cdots \cdots \cdots \cdots \cdots \cdots \cdots \cdots \cdots \cdots \cdots \cdots \cdots \cdots
\end{aligned}
$$

地盤の深部では波浪による間隙水圧変動は減衰するた め, 式 (12) の近似表現による鉛直有効応力変動の值は 地盤の深部では一定值（海底面の波圧值）に近づく。一 方, 式（11）の Hooke の法則を考慮した変動の值は地 盤の深部で 0 に近づく．そのため地盤深度が増すほぼ両 者は大きく食い違うようになる。

酒井ら ${ }^{13)}$ の図一 4 から, 液状化が生じるのは $G / \beta$ の 值が 1 以上の場合に限られる. $G=1.0 \times 10^{8} \mathrm{~N} / \mathrm{m}^{2}$ の場 合には, $\beta$ は逆に $1.0 \times 10^{8} \mathrm{~N} / \mathrm{m}^{2}$ 以下の場合に限られる. またその深さは波高の半分以下，波高が $4.0 \mathrm{~m}$ の場合 には $2.0 \mathrm{~m}$ までである. Fig. 9 は, Fig. 2 と同一の条件 で $\beta$ のみを $1.0 \times 10^{6} \mathrm{~N} / \mathrm{m}^{2}$ と変えた場合の $z=2.0 \mathrm{~m}$ 以 浅の部分についての両者の鉛直分布を示している. 図か

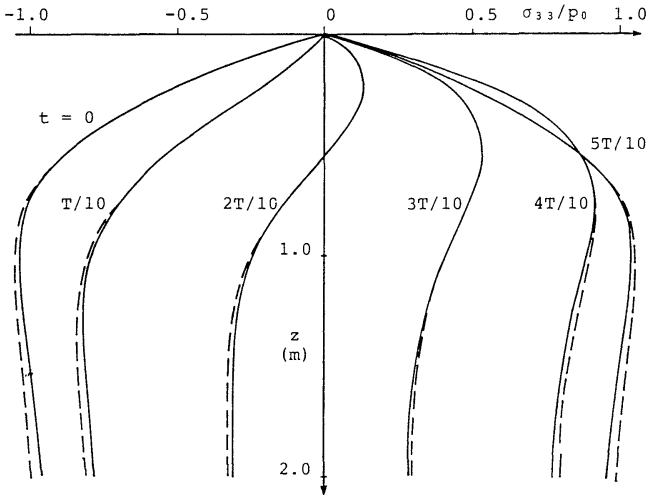

Fig. 9 Comparison of vertical effective stress variation calculated from Hooke's law ${ }^{10)}(-)$ and porewater pressure $^{3 \prime}(--)$

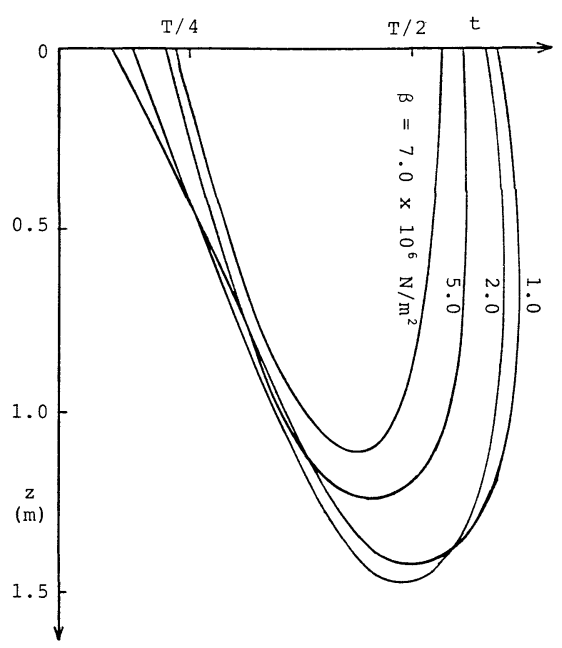

Fig. 10 Effect of effective bulk modulus of porewater on liquefaction depth.

ら液状化が生じる海底面付近の領域では両者の差は小さ く，およそ一致していることがわかる。この場合は $G /$ $\beta=1.0 \times 10^{2}$ であるが， $G / \beta=1.0$ となる $\beta=1.0 \times 10^{8}$ $\mathrm{N} / \mathrm{m}^{2}$ の場合についても検討の結果, $z=2.0 \mathrm{~m}$ 以浅の 領域については両者の差は小さいことがわかった. 以上 のことから，液状化を議論するにあたっては式（10）が ほぼ適用できるといえる.

\section{（3）海底地盤液状化の発生とその深さ}

酒井ら ${ }^{13)}$ は式（10）を用いて鉛直有効応力の減少を計 算し，有効応力ゼロ領域の深さに影響を及ぼすパラメー タ一の影響を明らかにしている. Fig. 10 は，酒井ら ${ }^{13)}$ の図一 3 の左の図と同じもので, 砕波帯のような浅い海 域での波浪による海底地盤内の鉛直有効応力ゼ口領域に 対する間隙水の有効体積弾性係数 $\beta$ の影響を示したも のである、ただし酒井ら ${ }^{13)}$ の図一 3 の横軸のとり方に誤 


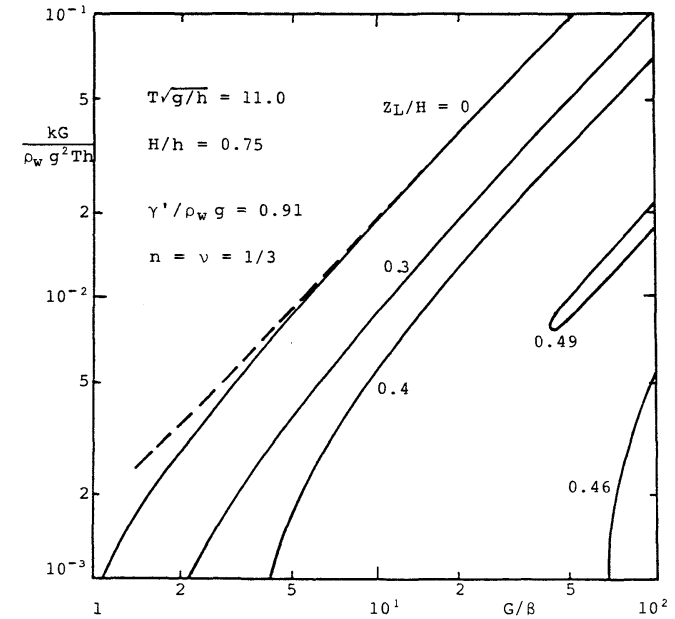

Fig. 11 (a) Liquefaction depth due to waves $(T \sqrt{g / h}=11.0$, $H / h=0.75$ ).

りがあり，修正している，この場合，式（10）の水中土 被り圧は地盤の水中単位体積重量 $\gamma^{\prime}$ と地盤深度 $z$ の積 で与え， $\gamma^{\prime}=0.91 \rho_{w} g$ とした. 間隙水の有効体積弾性係 数の影響を調べるため, 間隙水有効体積弾性係数 $\beta$ の みを変化させて有効応力ゼ口領域の発生およびその大き さの変化を調べたものである. 他の計算条件は酒井らと 同一で, Fig. 2 の条件と同じである．眓からわかるよう に, $\beta$ が減少するほど有効応力ゼロの発生領域が大きく なる。

また酒井らは 3.（1）と同じ考えで式（10）を無次元 化し，有効応力ゼロ領域の深さ $z_{L}$ に及ぼす無次元パラ メーターの影響を検討した。 その際の右辺第 1 項の土被 り圧の無次元表現は, $2 \cdot \gamma^{\prime} / \rho_{w} g \cdot z / H$ となる. 計算条 件は，3.（1）とほぼ同じであり，地盤の水中単位体積 重量 $\gamma^{\prime}$ に関する無次元量 $\gamma^{\prime} / \rho_{w} g$ はその典型的な值之 して 0.91 としたが, $G / \beta$ の值の範囲は $1.0<G / \beta<1.0$ $\times 10^{3}$ としている. ただし以下の図では $1.0<G / \beta<10^{2}$ の範囲を示している.

酒井ら ${ }^{13)}$ の図一4を再度Fig. 11 (a) で示している. $G / \beta$ が増加するほどまた $k G / \rho_{w} g^{2} T h$ が減少するほど 海底地盤の鉛直有効応力がゼロになる領域の深さ $z_{L}$ の 無次元量 $z_{L} / H$ が増大することがわかる．ただし詳細に みると, 両者が増加および減少するにつれ，一度最大值 0.49 に達した後, 若干減少して一定值 0.46 になること がわかる.

$G / \beta$ と $k G / \rho_{w} g^{2} T h$ の影響は，次のように解釈でき る. 横軸 $G / \beta$ は, 3. (3) で述べたように $m$ を通して 境界領域解の相対的な大きさに関係し，その值が増加す ると境界領域解が相対的に大きくなる。 さらに，式 (4) から境界領域厚さが小さくなる。一方, 縦軸の $k G /$

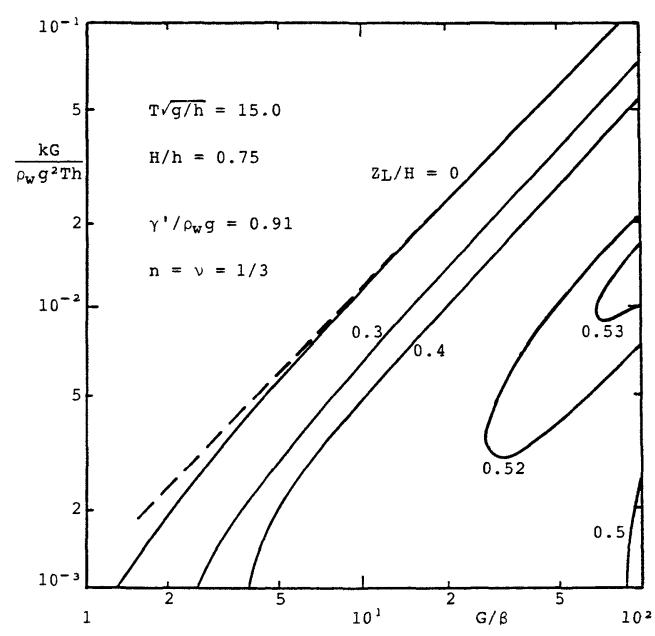

Fig. 11 (b) Liquefaction depth due to waves $(T \sqrt{g / h}=$ 15. $0, H / h=0.75)$.

$\rho_{w} g^{2} T h$ は，3.（３）で述べたようにその $1 / 2$ 乗が境界 領域厚さに比例する. そのため, $k G / \rho_{w} g^{2} T h$ が減少す ると境界領域厚さが小さくなる。 だちらの場合も間隙水 圧は海底面の付近の浅い領域で急激な減衰および位相の ずれを生じ，式（10）からわかるように波の谷の位相で 有效応力が減少し， $z_{L}$ が増加する.

ここでは図の (a) の場合の $T \sqrt{g / h}$ と $H / h$ の值以 外に, $T \sqrt{g / h}=15.0, H / h=0.50$ の值の場合につい ても計算を行った。そのうちの 1 つの場合の結果を図の

(b) に示す. $T \sqrt{g / h}$ が 15.0 に増加すると等值線全 体が右斜め下に平行移動し, 最大値が若干増加すること がわかる.また，図に示さなかったが $H / h$ が 0.50 に 減少すると,やはり等值線全体が右斜め下に平行移動し, しかも最大值はかなり減少する $\left(z_{L} / H=0.32\right) . T$ $\sqrt{g / h}=15.0, H / h=0.50$ の場合も, 等值線全体が右 斜め下に平行移動する一方, 最大値は $T \sqrt{g / h}=15.0$, $H / h=0.75$ の場合亡ほぼ同じであった。

図中の破線は $z_{L} / H=0$ の曲線の直線部分を延長した ものであり，その直線を次式

$$
k G / \rho_{w} g^{2} T h=\text { const. } \times G / \beta
$$

で表わすと, const. の值は $T \sqrt{g / h}$ 之 $H / h$ の値の 4 つの組合せに対して，以下のようになる.

$$
\begin{array}{rr}
T \sqrt{g / h}=11.0, & H / h=0.75: 2.0 \times 10^{-3} \\
& 15.0 \\
11.0 & 0.75: 1.2 \times 10^{-3} \\
15.0 & 0.50: 9.0 \times 10^{-4} \\
0.50: 7.5 \times 10^{-4}
\end{array}
$$

この式は, 地盤が波の谷の位相で液状化する限界条件を 示すものと考えられ，この式で与えられる值より $k G / \rho_{w} g^{2} T h$ の值が小さいと, 波の谷の位相で液状化が 生じることを意味する. 


\section{5. 結 論}

（1）波浪によって海底地盤内に生じる間隙水圧変動 の解に関して, 浸透流としての解 ${ }^{16)}$, Yamamoto $~^{6)}$ の Biot の圧密式 ${ }^{9)}$ 解いた厳密解および同じくBiot の式 を解いた Mei and Foda ${ }^{10)}$ の境界領域近似の解を比較 し，3 者の適用範囲を砕波帯のような浅海域を対象とし て無次元表示した，その結果，地盤骨格のせん断弾性係 数 $G$ 亡間隙水の有効体積弾性係数 $\beta$ の比が大きいほど, また透水係数 $k$ 亡 $G$ の積に比例する無次元量が小さい ほど, 厳密解を用いる必要はないが浸透流の解を用いる ことができず，境界領域近似の解を用いなければならな いようになることがわかった。

(2) 現地観測 ${ }^{18)}$ との比較の結果, 現地海岸の海底地 盤内の間隙水圧の変動は, 境界領域近似解の適用範囲に あり，その解によってほぼ説明し得ることがわかった。

（3）波による海底地盤内鉛直有効応力変動を水中土 被り圧と海底面での波圧変動の和から間隙水生変動を差 し引く形で与える近似的な表現は，波の谷の位相で地盤 の有効応力が 0 になる可能性がある海底面付近では妥当 であることがわかった。

（4） $G / \beta$ が増加するほよ゙，また $k G$ に比例する無 次元量が減少するほど，地盤表面付近の鉛直有効応力が 波の谷の位相で 0 になる可能性およびその領域の深さが 増し, 砕波帯の波のような条件下では, 波高の半分程度 に達することがわかった。

謝辞: 本研究においては, 岩垣雄一 京都大学名 誉教授 (現・名城大学理工学部教授), 土屋義人 京都大 学防災研究所教授および前野賀彦 舞鶴工業高等専門学 校助教授の助言を得たことを記して謝意を表する.また， この研究の一部は, 平成元年度文部省科学研究費, 国際 学術研究 (代表 : 舞鶴工業高等専門学校 前野賀彦助教 授，No.01044137）によったことを付記する.

\section{参 考 文 献}

1）名合宏之：変動水圧による砂層の液状化に関する研究, 第 26 回水理講演会論文集, pp. 589 594, 1982.

2）善 功企：波力を受ける構造物と海底地盤の動的挙動, 1985 年度（第 21 回）水工学に関する夏期研修会講義集, pp. B-4-1-16, 1985.

3）善 功企・山崎浩之・渡辺 篤: 海底地盤の波浪による 液状化および高密度化, 運輸省港湾技術研究所報告, 第
26 巻, 第 4 号, pp. 125 180, 1987.

4) Nago, H. and Maeno, S. : Pore water pressure in sand bed under oscillating water pressure, Memoirs. of the School of Eng., Okayama Univ., Vol.19-1, 1984.

5）酒井哲郎・間瀬 肇・松本明男：波浪による傾斜海底地 盤の応答, 第 35 回海岸工学講演会論文集, pp. 737 741, 1988.

6) Yamamoto, T., Koning, H. L., Sellmeijer, H. and Van Hijum, E. : On the response of a poro-elastic bed to water waves, J. of Fluid Mech., Vol. 87, part 1, pp. 193 〜206, 1978.

7) Madsen, O.S. : Wave-induced pore pressures and effective stresses in a porous bed, Géotechnique, Vol.28, No. 4, pp. 377 393, 1978.

8) Okusa, S. : Wave-induced stress in unsaturated submarine sediments, Géotechnique, Vol.35, No.4, pp. 517 — 532, 1985.

9) Biot, A. : General theory of three-dimensional consolidation, J. of Appl. Phys., Vol. 12, pp. 155 164, 1941.

10) Mei, C. C. and Foda, M. A. : Wave-induced responses in a fluid-filled poro-elastic solid with a free surface-a boundary layer theory, Geophys. J. R. astr. Soc., Vol. 66, pp. 597 631, 1981.

11）酒井哲郎・間瀬 肇・松本明男：波浪による海底地盤内 の間隙水圧変化に及ぼす慣性項の効果, 第 32 回水理講演 会論文集，pp. 589～594，1988.

12）酒井哲郎・服部明彦・間瀬 肇：波浪による海浜地盤応 答における海底摩擦の効果, 第 36 回海岸工学論文集, pp. 794 798, 1989.

13）酒井哲郎・服部明彦・間瀬 肇：波浪による砕波帯海底 地盤の有効応力ゼ口領域の発生, 海洋開発論文集, Vol. 5 , pp. $79 \sim 84,1989$.

14) Sleath, J.F.A. : Wave-induced pressures in beds of sand, J. of Hydraulics Div., Proc. of ASCE, HY2, pp. 367 378, 1970.

15) Fung, Y.C. : Foundations of Solid Mechanics, Englewood Cliffs, NJ : Prentice-Hall, pp. 195 197, 1965.

16) Finn, W.D., Siddharthan, R. and Martin, G. R. : Response of seafloor to ocean waves, J. of Geotech. Eng., ASCE, Vol. 109, No. 4, pp. 556 571, 1983.

17) Mei, C. C. : The Applied Dynamics of Ocean Surface Waves, World Scientific, pp. 673 705, 1983.

18）善 功企・山崎浩之・佐藤 泰：波浪による海底地盤中 の応力変化に関する現地観測, 海洋開発論文集, Vol. 5, pp. 85 90, 1989.

19）前野賀彦・酒井哲郎・間瀬 肇：波浪による砂層の液状 化傾向と波形勾配の関係，海洋開発論文集，Vol. 4, pp. 5 10, 1988.

(1989.12.4 • 受付) 